\title{
A Burocracia Federal Americana como Grupo de Poder Político (*)
}

\author{
Mark W. Cannon \\ Proǵrama de Desenvolvimento Uurbano \\ da Venezuela \\ Instituto de Administração Pública \\ de Nova York \\ R. Joseph Monsen \\ Colégio de Administração de Emprêsa \\ Universidade de Washington \\ PETER PRINA \\ Departamento de Ciência Politica \\ Colégio Masculino de Clermont \\ Tradução de Stella C $_{\text {AVAlcanti }}$
}

$\mathrm{P}$

CDE-SE dizer das burocracias que são estratégias institucionaliza las para a consecução de objetivos administrativos através do eslồrço combinado de muitos servidores. São métodos de organizáção da conduta social, tendo em vista a transformação de problemas excepcionais em obrigações de rotina para os técnicos e tend

A razão decisiva do progresso das burocracias é a vantagem puramente técnica que levam sôbre qualquer outra forma de organização. Max Weber declarou que "o mecanismo burocrático plenamente desenvolvido se compara com as outras organizações do mesmo modo que a máquina se compara com os meios não mecânicos de produção." ${ }^{(2)}$ Nos casos em que existem apenas

$\left(^{\star}\right)$ Philippine Journal of Public Administration, vol. IX $\mathrm{n}^{\circ} 2$, páginas 108-127. Este artigo se fundamenta amplamente na obra de R. JosEPH MonSEN e Mark W. Cannon Os Criadores da Politica Coletiva; Grupos Americanos 1965. Usado por permissão de Mac Gais de Mc Graw-Hill Book Co., Inc.,

(1) PETER M. BLAU A Dill Company. of Chicago Press, 1965), pág. 202

(2) MAX Weber $V$ antag

edição de H. H. Gerth e C. Wrigentécnicas da Organização Burocrática, na logia", (New York: Oxford Wright Mills, "Max Weber; Ensaios de Socio- 
pequenas instituições, em que a vida é simples, e em que as relações interpessoais são diretas, não se encontra uma situação que possa ser denominada de burocrática.

Há 75 ou mesmo 100 anos atrás, os Ministros da Coroa e os Membros do Parlamento mais escrupulosos podiam dominar as ninharias que compunham a politica... Sir James Graham podia interessar-se pessoalmente por tudo o que sucedia no Almirantado, enquanto Palmerton era, pràticamente, o Ministério do Exterior, redigindo de próprio punho a importante correspondência do seu Departamento e, por vêzes, efetuando a sua politica sòzinho. Mesmo em épocas mais recentes, Lord Salisbury, que não confiava em seus assessôres, ignorava-os com relativa impunidade. ( $\left.{ }^{4}\right)$

Antes do comêço do século XX, mesmo a burocracia civil das nações maiores e mais poderosas do mundo podia ser considerada bàsicamente como um instrumento utilizado para executar a politica estabelecida pelos legisladores. LORD WELBY pensava, sem dúvida, nesses têrmos, quando declarou que a principal função de qualquer servidor civil era fazer o que lhe fôsse ordenado. $\left({ }^{5}\right)$

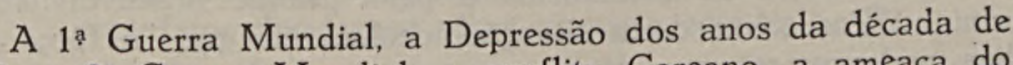
1930, a 2: Guerra Mundial, o conflito Coreano, a ameaça do comunismo e o grande desenvolvimento urbano fizeram expandir-se as funções do govêrno federal a um grau jamais sonhado na passagem do século.

No presente estudo, o têrmo "Burocracia Civil" refere-se aos empregados do govêrno federal que preenchem os quadros das inúmeras repartições federais, exceto os dos grupos militares que serão considerados separadamente. Tais empregados são os técnicos que tornam possível operar numa escala baseada na coordenação de muitas funções especializadas.

O crescimento numérico, por si só, já deu à burocracia civil uma posição de poder crescente no processo governamental americano. No entanto, a maior parcela do poder da burocracia adveio da natureza técnica das funções do govêrno e do crescente reconhecimento que as burocracias adquiriram da sua posição na

(3) Marshall E. Dimock, A Burocracia Auto-Examinada, "Revista de Administração Pública", vol. 4, n 3 (Verão, 1944), pág. 198.

(4) J. Donald Kingsley, A Execução da Politica in Leitura sôbre a Butocracia de Robert K. Merton, Ailsa P. Gray, Barbara Hockey e Hanan S. Selvin (Glençoe, Ill.: The Free Press, 1952), pág. 216.

(5) Ibid., pp. 216-217. 
sociedade americana em geral. H. J. LASKI observou o poder crescente da burocracia nos seguintes têrmos:

Como conseqüência muito lógica do desenvolvimento das funções governamentais, o serviço civil se acresceu continuadamente de maior poder no Estado. O fato de que os servidores mais graduados são permanentes; o conhecimento que êstes inevitàvelmente adquirem através da familiaridade diária com os problemas; a necessária dependência de qualquer ministro para com êstes servidores no que tange à matéria que dá corpo e alma a princípios apenas formulados; a inescapável confiança dos ministros nestes servidores para avaliação do ideal contra o real - tudo isto contribui para o acúmulo de autoridade de tais funcionários num grau jamais atingido em eras passadas. $\left({ }^{6}\right)$

Qualquer decréscimo do poderoso papel desempenhado pelas repartições do govêrno parece pouco provável na medida em que as tendências contemporâneas convergem no sentido do aumento de dimensões e funções do govêrno. O diretor executivo da Liga Nacional dos Servidores Civis afirmou que o futuro da burocracia nos Estados Unidos será tremendamente influenciado pela ameaça mundial do comunismo e pelo grande desenvolvimento urbano. Por causa desta situação, declara êle que "a fôrça nos dias modernos requer a fôrça no govêrno. A despeito das ilusões em que labora muita gente, o govêrno é grande, complicado e necessário." ( $\left.{ }^{7}\right)$ Com referência à ameaça do comunismo, o exSecretário da Defesa, NeIl Mc Elroy disse:

Nossa civilização está trancada num vasto contexto de ideologias dentro do qual a própria sobrevivência da liberdade humana corre perigo. Nesta luta recai sôbre nós a forçosa liderança do mundo livre, não procurada, porém obrigatória. Para enfrentarmos esta obrigação é essencial que construamos nossa fôrça em cada setor da sociedade. E eu acredito estar claro que no âmago desta sociedade reside o nosso govêrno. Precisamos ter um govêrno forte e capaz para sermos capazes de liderar o mundo. $\left({ }^{8}\right)$

O papel de liderar o mundo significa não apenas uma ampliação do papel do govêrno em têrmos de capacidade para conter

(6) HaRold J. LASKI, A Democracia em Ação (Chapel Hill, N.C.: The University of North Carolina Press, 1935), p. 100.

(7) James R. Watson, "O Serviço Público de Amanhã, in "Bom Govêrno", vol. 80, n̊ $^{\circ} 3$ (março, 1963), pág. 9.

(8) Ibid. 
qualquer agressão direta de uma potência comunista, mas também coloca sôbre os Estados Unidos a responsabilidade de apresentar ao mundo inteiro o exemplo de um sistema que ofereça grandes oportunidades econômicas e sociais - um sistema que está sendo observado de bem perto durante a revolução mundial de crescentes expectativas.

Desde a Depressã́o da década de 1930 , a opinião pública não tolera mais depressões econômicas prolongadas. Atribui-se ao govêrno a responsabilidade de tomar medidas saneadoras.

Tal mudança geral nas atitudes do público face à função do govêrno representa um dos fatôres básicos com respeito à ideologia da burocracia. Em 1956, o ex-Presidente EISENHOWER disse:

A experiência ... de muitos anos induziu gradualmente o povo americano a alargar o seu conceito de govêrno. Nós acreditamos com a mesma convicção de nossos pais no progresso econômico através da livre iniciativa e da competição, e ressentimos com igual intensidade qualquer imiscuição desnecessária do govêrno nos assuntos privados. Mas também aprendemos a crer que o progresso não precisa caminhar com a irregularidade do passado, e que o Govêrno Federal tem capacidade para moderar as flutuações econômicas sem se tornar um fator dominante sôbre a nossa economia. ( $\left.{ }^{9}\right)$

A par da mudança de atitude quanto ao papel do govêrno, veio a crescente constatação de quanto a nação depende da burocracia para o seu bem-estar e segurança. Com efeito, sem as contribuições dos técnicos das repartições governamentais, nosso sistema politico não poderia satisfazer as demandas cada vız mais complexas que se lhe apresentam. O Presidente e os membros do Congresso não podem controlar, por completo, o modo de execução da politica, o que conseguiam em tempos passados. Hoje êles mesmos se vêem pedindo a assistência das burocracias, para a criação da politica, o que permite aos servidores civis atuarem na dupla qualidade de iniciadores e de executores da politica. Como observou Wallace S. Sayre:

Os altos funcionários executivos e os profissionais do serviço federal se encontram, com o Presidente e o Congresso, no centro do processo da política nacional. Acha-se em suas mãos grande parte do processo de elaboração de decisões. A coleta de informações, a des-

(9) "Relatório Econômico do Presidente", transmitido ao Congresso em 24 de janeiro de 1956, pág. 10, citado por MARver H. Bernstein, in "A Função do Executivo Federal" (Washington, D.C.: The Brookings Institution, 1958), pág. 205. 
coberta de alternativas, a avaliação analitica destas escolhas, a sintese de riscos e oportunidades em recomendações inovadoras mas realistas, o processo de discussões e acomodações que transforma as propostas em políticas aceitas, a execução dos planos e programas resultantes - em cada um dêsses estágios, a participação efetiva dos funcionários executivos superiores e dos profissionais é indispensável ao Presidente e ao Congresso, sendo essencial à criação e execução de atitudes ;úblicas viáveis. $\left({ }^{10}\right)$

Todos os participantes do processo de criação política do govêrno tornaram-se dependentes das repartições governamentais, de uma maneira ou de outra. A complexidade do sistema de vida americano, o mecanismo por meio do qual a vontade do público se converte em leis, bem como o desejo dos setores do govêrno e dos grupos de poder de influenciar os processos de criação de normas e política, todos se combinam para colocar a burocracia numa posição inteiramente diferente de tudo o que poderiam prever os autores da Constituição.

Poucos são os aspectos da vida na América que escapam ac's interêsses ou normas do govêrno federal. Os dois e meio milhões de servidores civis do govêrno federal criam uma burocracia tão vasta que quase ninguém pode abranger tôdas as suas ramificações. (11) O govêrno féderal norte-americano é a entidade que mais gasta no mundo. O fato de ser êle, na América, a entidade que mais gasta e que fornece o maior número de empregos, dá-lihe um poder tremendo, extensivo à burocracia que o sustenta.

Para se compreender a maneira pela qual a burocracia atua como grupo de poder é necessário observá-la como um conjunto de muitas repartições, cada qual funcionando como grupo de poder numa esfera especifica de operação, para a consecução de objetivos específicos. Ademais, observa-se que, enquanto cada entidade luta pela expansão das próprias funções e jurisdição, a burocracia, de modo geral, encoraja a aceitação da preponderância
do govêrno.

Tais organizações se empenham em gastar bilhões de dólarés por ano em projetos que afetam cada segmento do público americano. As grandes quantias de dinheiro estimulam o uso do (10) WALlace S. SAYre: O Serviço Público, na Comissão Presidencial
sôbre Objetivos Nacionais, "Objetivos para os Americanos" (Englewood Clif́fs,
N.Y.: Prentice-Hall, Inc. N.Y.: Prentice-Hall, Inc.. 1960), pp. 292-293.

(11) V. SAYre in Objetivos para os Americanos, pág. 286. Hâ um quadro demonstrativo dos empregos do govêrno dos Estados Unidos em 1958, por nivel de govêrno, no trabalho de Salyre "O Serviço Civil Americano", riçno" (New York; Frederick A. Praeger, Inc., 1961), pág. 123. 
poder e da política. O processo politico não pode ser separado do econômico nos Estados Unidos. Não se pode descortinar açốes coletivas que afetem a economia sem afetar a politica igualmente. Na medida em que se encarregam de gastar êste dinheiro, as repartições se envolvem em politicas de poder.

O papel hoje desempenhado pelas repartiçóes administrativas no processo governamental apresenta certas semelhanças com o funcionamento dos grandes grupos formais de poder. As burocracias não apenas ajudam a exercer a lei, também se empenham em exercer pressão efetiva sôbre as pontos críticos do processo político, colocando-os entre os grupos de poder que contribuem para forjar a politica coletiva. J. LeIPER FreEman comentou da seguinte maneira o papel politico das burocracias:

Por se encarregar de aspectos especiais e limitados da politica coletiva, a burocracia pública se assemelha, até certo ponto, ao grupo privado comum de pessoas. E um ponto de referência para os individuos interessados nos mesmos assuntos... Nesse" processo representativo, talvez a função mais importante da burocracia seja a de promover a idéia da importância de sua área especifica de interêsse - seja êle a educação, o poder aéreo, ou a saúde mental. A burocracia também estimula soluções especiais para os problemas políticos da sua área. E, por fim, ela promove os objetivos do interêsse particular dos seus membros enquanto "burocratas." $\left.{ }^{(12}\right)$

As repartições federais ocupam o que bem pode ser considerado como o ponto mais vantajoso do processo de criação politica. De fato, o fator essencial do seu poder é a sua posição estratégica. As repartições administrativas gozam de contato cotidiano com os Congressistas, os Comitês do Congresso, e os altos funcionários do setor executivo. Podem confiar, com freqüência, no apoio da clientela. Grande parte do poder de algumas repartiçóes emana do apoio de seus empregados, que em alguns casos são organizados e atuam por si mesmos como grupos de poder.

As atividades de pressão das repartições componentes da burocracia dirigem-se, em geral, no sentido de expandir os podêres de criação de política e de criação de normas e, especificamente, no sentido de obter a "ordem de avanço" necessária ao estabelecimento, alteração, ou incremento das funções que são do interêsse dos chefes executivos, dos empregados e da clientela da repartição específica. Tais objetivos são, contudo, sempre apresentados como do interêsse público.

(12) J. Leiper Freeman. A Burocracia em Politicas de Pressão, in "Os Anais", vol. 319 (setembro, 1958), pág. 11. 
A burocracia difere de outros grupos de poder porquanto, na qualidade de empregados do govêrno, seus elementos são tidos como neutros em matéria política - na certa, muitos membros da burocracia se apressariam em confirmar esta posição. Älém disso, não reconhecem nenhum ponto de vista ideológico que possa ditar a maneira pela qual êles apreciarão, em conjunto, um problema especifico. Foi visto, em recente estudo, que os empregados federais não votam em "bloco", mas divergem substancialmente entre si e que há um grupo considerável de correspondência entre o tipo de voto dos empregados federais e o da sociedade em geral (13)

É provável que muitos membros da burocracia se oponinam enfàticamente à própria sugestão de que há uma ideologgia ligada à burocracia. Muitos, na certa, diriam que se dedicam a executar as funções que sua repartição foi autorizada a desempenhar, e que são necessárias ao interêsse público. O que os membros da burocracia provàvelmente não reconhecerão é que, enquanto os membros das diferentes repartições encaram dessa maneira a sua situação no processo governamental, se vai estabelecendo uma ideologia definida, embora meio velada. A ideologia repousa como um lençol sôbre cada segmento da sociedade americana. É a soma total das atitudes dos membros de cada repartição quanto ao papel de suas próprias repartições e quanto a sua essencialidade para o bem-estar do público. Resulta dos fatôres inerentes ao sistema da burocracia e do esfôrço que fazem as repartições para provar a legitimidade da própria existência.

A Ideologia será discutida a seguir mas far-se-á primeiro ıma análise da posição da burocracia no processo governamental dos Estados Unidos. Esta posição é fator básico para a compre. ensãc da ideologia da burocracia, bem como de sua eficácia enquanto comunidade de poder. Devido à sua posição estratégica, a repartição federal está diàriamente envolvida numa série de atividades que se destinam a legitimar sua existência. $O$ sucesso de tais esforços está muito ligado à vitalidade da ideologia.

\section{POSIÇÃO ESTRATÉGICA DAS BUROCRACIAS CIVIS}

Nesta seção, mostrar-se á que a principal fonte de poder da burocracia é a sua posição dentro do esquema do govêrno. Dos fatôres que criam e sustentam a ideologia da burocracia, nenhum é tão significativo quanto a posição estratégica das repartiçöes no processo politico.

(13) Carta de Dalmas H. Nelson, Universidade de San Fernando Valley,
janeiro de 1964 . 


\section{RELAÇÃO COM OS LEGISLADORES}

A relação entre os legisladores individuais e as repartições é uma relação de continuidade. "As repartições administrativas não esperam que uma proposta especifica se imponha à legislatura para cultivar relações harmoniosas com os legisladores. Mantém-se um processo continuo de ligação legislativa." (14) As repartições estabelecem vinculos mais fortes com os legisladores que ocupam posições-chave nos comitês com que estas repartições lidam mais frequientemente.

A localização estratégica das repartições em Washington, D.C., perto da Colina do Capitólio, facilita a ligação. Cada repartição principal tem uma equipe cuja função é manter estreita ligação com os congressistas. Dentro do Departamente de Estado esta função atingiu o status de Carteira - a Carteira de Relações com o Congresso. Esses competentes funcionários recebem e respondem com cortesia e rapidez os pedidos dos congressistas. Além de fornecerem informações exatas e vitais, as repartiçôes administrativas executam outros favores" para manter vinculos amistosos com os congressistas.

Peter Woll observou:

Diversos grupos privados mantêm vastos quadros de "lobbyistas" ( $\left.{ }^{*}\right)$ em Washington, porém não gozam êstes do mesmo acesso nem dos mesmos privilégios das repartições administrativas. Não podem conduzir os congressistas em passeios gratuitos pela Europa, arranjar assistência médica gratuita, facilitar a vida dos congressistas em inúmeros outros casos. As repartiçõe; administrativas fazem tudo isso e na maior parte não suscitam inquéritos. Quando os grupos privados fazem o mesmo são acusados de "subôrno" ou coisa pior. $\left({ }^{15}\right)$

Os empregados das repartições que trabalham no interior mantêm, freqüentemente, relações de amizade com os legisladores da sua zona. Como êstes funcionários estão próximos dos grupos de que dependem os congressistas e representam parcialmente êsses grupos, os congressistas têm todo o interêsse em nutrir êsses laços de proximidade. Por exemplo, um senador, indo para casa durante o curto recesso da Páscoa, obtém a melhor informaçàs sôbre os sentimentos dos fazendeiros ao conversar com o diretor

(14) FREEMAN, op. cit., pág. 14.

(*) Lobiyista (Lobby, lobbyism, lobbyist): grupo de pessoas empenhadas em influenciar os podêres públicos e especialmente os membros do poder legislativo em favor de uma lei ou de uma decisão politica (N.T.).

(15) Burocracia Americana (New York: W. W. Norton \& Company. Inc., 1963), pág. 135. 
regional da Administração do Lar do Fazendeiro que, para aprovar os empréstimos aos camponeses, ouve-lhes continuamente os comentários e as queixas.

As ligações entre os congressistas e as repartições do Govêrno Federal comumente atingem seu ponto culminante entre os funcionários de carreira e os membros do Congresso de mandatos mais prolongados. A êsse respeito, Marshall E. Dimock disse que "se o programa afeta a legislação, os funcionários de carreira podem conversar confidencialmente com os membros do poder legislativo com os quais cultivaram relações de intimidade durante anos." (16)

\section{Relações entre Repartições. Grupos de Clientela e Comitês do Congresso}

Um tipo de apoio que as repartiçêes buscam para seus programas é o que vem invariàvelmente dos grupos de clientes da repartição - aquêles grupos cujas atividades são sèriamente afetadas pela repartição e que, por sua vez, influenciam o modo de execução dos programas da repartição. A repartição torna-se foco de grupos, por vêzes diversos, de clientes. (17)

Devido à freqüente ligação entre as repartições e sua clientela, é comum as repartições receberem um apoio que redunda em forte pressão sôbre o Congresso. Os grupos que se reúnem em apoio das diferentes repartições são, comumente, os mais poderosos, politica e econômicamente. Tôda repartição vê nos seus grupos de clientes a prova da legitimidade da sua existência. Ao mesmo tempo, os grupos vêem na repartição um protetor e porta-
voz.

O papel de criação de normas da repartição administrativa é básico para a estreita ligação entre as diversas repartições e seus clientes. Desde que a maior parte da legislação incidente sôbre os grupos de poder é, na América, estrutural e desdé que recai sôbre a repartição administrativa especifica a função de materializar a legislação, os grupos formais de poder atingidos mostram-se ansiosos por manter uma associação saudável com a repartição. ${ }^{18}$ ) Isto ajuda a explicar porque muitos grupos tentam influenciar o poder executivo com a mesma ênfase que usam
para o legislativo.

Num estudo sôbre as relações entre as repartições do govêrno e o público, mostrou-se que "a tarefa de disseminar informações

(16) DIMOck, op. cit., pág. 203.

(17) Woll, op. cit., pág. 54.

(18) Harmon ZEIGLer: Grupos de Interêsse na Sociedade Americana (Englewood Cliffs, N.J.: Prentice-Hall, Inc. 1964), pág. 278. 
sôbre os programas era, em grande parte, atribuída a associações voluntárias e a grupos econômicos - de negócios, de trabalho, e de interêsses especiais." (19) Como as repartições do govêrno são um tanto restritas em atividades informnativas, êste apoio é muito significativo.

Dada a amplitude com que as repartições administrativas são capazes de reforçar suas posições ao aliarem-se a grupos privados, comentou um escritor que o administrador inteligente fará todos os esforços para manter abertos of canais entre sua repartição e os grupos afetos às suas operações. "Com efeito, além da questão de proteger a independência de visão, o úrico problema é decidir se êstes canais devem ter uma base formal ou ficam no terreno do contato pessoal informal." $\left.{ }^{20}\right)$

Entre as repartições administrativas e os comitês dic Congresso há sobretudo uma associação de interdependência. Os funcionários das repartições são sistemàticamente convidados a prestar depoimento nos inquéritos dos comitês. A origem dessa necessidade jaz, principalmente, na qualidade técnica da legislação de nossos dias. A maioria dos funcionárics administrativos torna-se especialista em seus setores. O poder legislativo, em seus comitês, procura conselho e informação de natıreza técnica em fontes externas aos seus componentes.

Os grupos privados, em geral, contribuem muito para assegurar as boas relações entre os comitês do Congreşo e a repartição. Se são grupos fortes e de acesso à cúpula dos comitês do Congresso, a repartição por êles apoiada terá visivel acesso.

Tanto os comitês do Congresso quanto os grupos de clientes podem ver na repartição o instrumento de comunicação, apcic $p$ pressão mútuos. O que é, às vêzes, desprezado é que o "intermediário" adquire, comumente, maior poder no processo. Quando a legislação é formulada por uma repartição, os comitês do Congresso e os grupos privados que tenhan procurado em diversas ocasiões e o auxilio da repartição costumam apoiá-la com entusiasmo.

\section{David Truman observou êsse parentesco:}

As relações dos grupos de interêsse com o Congresso e especialmente com os seus comitês permanentes são... bastante mais amplas do que se poderia depre-

(19) Morris Janowitz, Deil Wright e William Delany, A Administração Pública e o Público, em ediçăo de Amitai Etzioni: "Organizaçốes Complexas: Leitura de Sociologia" (New York; Holt, Reinhart and Winston, Inc. 1961), pág. 283.

(20) Avery Leiserson, Grupos de Interêsse na Administração in "Elementos da Administração Pública" de Fritz Morstein Marx (Englewood Cliffs, N.J.: Prentice-Hall, Inc. 1959), pág. 296. 
ender de um contato superficial com os negócios de Washington. Em uma porção de assuntos de rotina e não-controversos, o examinador cuidadoso encuntrará, via de regra, uma tranqüila colaboração entre os grupos, os comitês do Congresso e as repartições executitivas... $\left({ }^{21}\right)$

John A. VIEg afirmou: "hoje em dia observamos que muitas politicas nacionais ... provieram da colaboração triplice dos comitês do Congresso, dos funcionários administrativos e dos represantantes de grupos de interêsse particulares." (22)

É muito importante, nessa associação, o fato de que muitos membros dos comitês do Congresso se aliam estreitamente aos grupos formais de poder e às repartições administrativas por pressões dos seus contribuintes ou por interêsses pessoais. A maior parte dos homens de negócios, dos advogados e dos fazendeiros que ocupam o Congresso mantêm suas atividades profissionais. Grande número de congressistas agem como representantes de grupos de poder que procuram obter sanções legislativas. $\left({ }^{23}\right)$

\section{Aipoio do Chefe do Executivo e de outros funcionários da Alta Administração}

A posição estratégica das repartições federais não é, talvez, tão óbvia em outros setores do processo governamental do que quando o Chefe do Executivo ou outro alto funcionário administrativo atua em apoio da repartição que procura conseguir a aprovação às suas propostas. "Se ... o chefe da carteira e os funcionários do departamento que precisam da lei são capazes de obter uma declaração do Chefe do Executivo ao Comitê legislativo, uma nota à imprensa, ou um parágrafo de discurso favorável ao seu projeto, podem também exagerar as possibilidades de adoção dêste projeto." ${ }^{24}$ )

Há poucos anos, os estudiosos referiam-se sempre ao Presidente como o "Legislador-Mor" ou o "Criador de Leis." ( $(25)$

(21) "Grupos de Interêsse Organizados na Politica. Nacional Americana", in Junz, op. cit., pág. 132.

(22) John A. VIEG, O Crescimento da Adininistração Pública in MARX, op. cit., pág. 79 .

(23) Bertran M. Gross A Luta Legislativa: Estudo sôbre o Combate Social (New York: Mc Graw-Hill Book Co., Inc., 1953), pág. 93.

(24) FreEMAN, op. cit., págs. $15-16$

(25) V. Cinton Rossiter, A Presidência Americana (New York: Harcourt. Brace \& World, Inc., 1960), págs. 28-30 e Claudius O. JoHnson, 1960), págs. 497-513.
Americano (New York: Thomas Y. Crowell Company, 
Apesar das muitas razões que justificam êsse título, nenhuma é, talvez, mais significativa do que o fato de o legislativo procurar no Presidente uma liderança. Ao mesmo tempc, as repartições administrativas se esforçam por usar a popularidade e o poder do Presidente como meio de conquista do legislativo para as suas propostas. Como a maioria das repartições são chefiadas por homens designados pelo Presidente e como a maioria dos funcionários de alta posição merece o profundo respeito do Presidente, a repartição goza de posição invejável para obter o seu apoio. Muitos são os casos em que o apoio do Presidente ajudou uma repartição a vencer uma batalha em favor de projeto legislativo, a cujo respeito o Congresso oferecia resistência.

As repartições podem receber um apoio substancial para os seus projetos através de membros do gabinete e outros altos funcionários administrativos que prestam depoimento em inquéritos dos comitês e influenciam o Congresso, também, de outras maneiras. Tais funcionários mostram grande solicitude em obter aprovação para os projetos da repartiçąo. $O$ prestígio de suas posições torna-os poderosos nos inquéritos do Congresso e junto a congressistas individuais.

Não se pretende com tudo isto sugerir que as repartições podem funcionar sem contrôle. O Presidente e os seus assessôres diferem, por vêzes, das aspirações de seus subordinados administrativos. Por outro lado, o poder da burocracia é cerceado pela possibilidade de investigações do Congresso, destinadas a denunciar os servidores civis que ultrapassem os limites de sua autoridade legal.

\section{Apoio dos Empregados das Repartições}

"Uma das grandes reservas de fôrça politica à disposição dos líderes de repartições, em certos tipos de atividades legislativas, está nas organizações a que se filiam os seus empregados." $\left({ }^{26}\right)$ $\mathrm{O}$ apoio que os chefes executivos do govêrno podem receber dos empregados depende, em parte, da facilidade com que os empregados são informados e mobilizados. Isto parece ser mais fácil quando a organização formal é forte e coesa. Os projetos precisam também de beneficiar os empregados, ou, pelo menos, apelar para suas convicções ideológicas para ganhar o apoio máximo.

Como a maior parte dos empregados federais está espalhada pelo país, as repartições podem contar com seus empregados para influenciar diretamente muitos congressistas $e$, indiretamente, no

(26) Freman, op. cit., pág. 16. 
contato com o público. Nenhum grupo de empregados federais tem maior contato com o público do que os funcionários dos Correios. William C. Doherty, Presidente da Associação Nacional de Portadores de Carta, asseverou:

A única arma que os portadores de carta retinham (e ainda retêm) é o fato de serem estimados e admirados, como indivíduos e em grupo, pelo grande público americano, e de que visitam cada lar diàriamente, seis dias por semana. A conversa de velhos amigos entre o povo e os carteiros representa um tento formidável sôbre o Congresso. $\left({ }^{27}\right)$

O efeito que tem a associação entre os empregados dos Correios e o público sôbre o Congresso é bem realçado no estudo da Brookings Institution:

Por vêzes os sindicatos postais atingem tal fôrça que parecem quase capazes de ditar ao Congresso as suas condições de emprêgo. É um poder baseado em números e no fato de que seus membros se localizam em cada distrito eleitoral da nação. Nenhum outro grupo de empregados federais está em contato tão permanente com quase cada cidadão. $\left({ }^{28}\right)$

O apoio que uma repartição pode obier de seus funcionários, quando existe um alto grau de organização de empregados, foi exemplificado no caso da Lei de Tarifa Postal e Aumento Salarial aprovada pelo $85^{\circ}$ Congresso em 1958. Nesse caso, os objetivos dos funcionários postais eram o aumento das tarifas e a modernização do serviço postal. Junto com êstes objetivos veio o projeto de aumento salarial para os empregados do Departamento de Correios. Durante o tempo de deliberação do legislativo, as organizações de empregados postais desenvolveram amplas atividades "lobbyistas." No Relatório de Conferência da lei, os votos do Senado e da Câmara foram afirmativos por unanimi-
dade.

(27) William C. Doherty, O Carteiro, U. S. A. (New York: David Mc-Kay Co., Inc., 1960), págs. 26-27.

(28) Bernstein, op. cit., pág. 96. 
O Relatório da Fôrça-Tarefa Presidencial sôbre as Relações de Empregados e Chefes no Serviço Federal, concluído em outubro de 1961, mostrou que dos 2.277 .604 empregados civis fedezais 762.372 , ou $33 \%$ pediram inscrição na organização de empregados que se constituira para representar os empregados federais nas conversações com a chefia das respectivas repartições, sôbre condições de trabalho. $\left({ }^{29}\right)$ O relatório salienta, no entanto, que $33 \%$ não pode ser considerado como representativo de tôdas as repartições federais.

O Departamento de Correios, com 600.000 servidores, declara que $84 \%$ de seus funcionários são membros de organizações de empregados. Esta cifra que reflete a mais ampla organização de repartição pública tem influência tão decisiva sôbre a computação da percentagem geral do govêrno que prejudica o sentido da percentagem. Excluindo os Correios, 16\% dos funcionários das repartições restantes são membros de organizações de empregados. $\left({ }^{30}\right)$

As repartições que têm a maior percentagem de funcionários em organizações de empregados incluem: a Tennessee Valley Authority, $82 \%$; o Departamento do Tesouro, $46 \%$; e o Departamento de Mobilização Civil e de Defesa, 38\%. Há dezessete repartições que não têm nenhuma ou têm menos de $10 \%$ de funcionários filiados a organizações de empregados. ( $\left.{ }^{31}\right)$

O relatório também mostra que os dois sindicatos de empregados do govêrno mais procurados pelas repartições são a $\mathrm{Fe}$ deração Americana de Empregados Federais (filiada à AFL-CIO) e a Federação Nacional de Empregados Federais (não filiada). Os quadros que se seguem mostram o tamanho destas organizações. Deve-se notar que elas são apoucadas pelos dois sindicatos dos Correios, a Associação Nacional dos Portadores de Carta (AFL-CIO) e a Federação Unida de Funcionários Postais. Alguns dêsses grandes sindicatos sofreram altas e baixas no número de associados, mas seu crescimento liquido de 1951 a 1962 foi de 426.242 a 545.008 .

(29) "Práticas de Relações de Empregados e Chefes no Serviço Federal" (Washington, D.C.: outubro, 1961), pág. 11.

(30) Ibid., pág. 9 .

(31) Ibid., págs. 10-11. 


\section{SINDICATOS SELECIONADOS PELO CRITERIO DE MAIOR NÚMERO DE MEMBROS DO SERVIÇO FEDERAL}

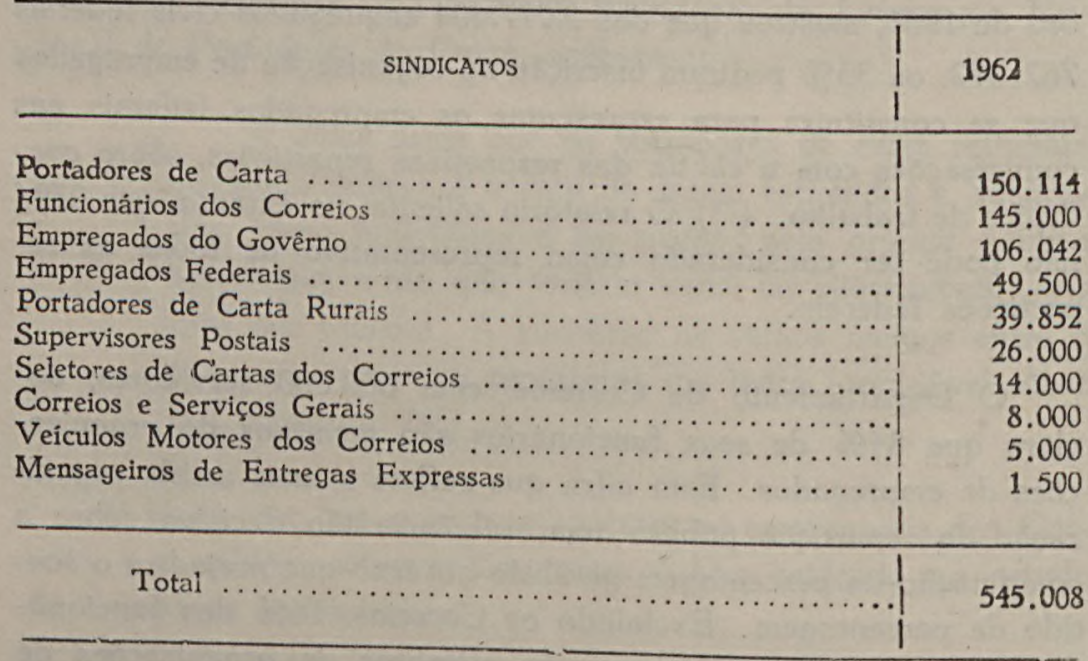

Fonte: Carteira de Estatistica do Trabalho, Divisão de Relações entre a Indústria e o Trabalho, outubro de 1963.

A capacidade dos altos funcionários da repartição para mobilizar os empregados tem um alcance que rião pode ser contemplado superficialmente. A medida que as repartições federais continuam a se expandir em tamanho e à medida que mais e mais repartições se espalham por todo o país, os congressistas sentem pressões crescentes das repartições, não apenas em Washington mas também nos seus Estados e Distritos.

O Decreto Executivo do Presidente Kennedy, de 17 de janeiro de 1962, baseado nas recomendações do relatório da FôrçaTarefa sôbre as Relações de Empregados e Chefes no Serviço Federal, reconheceu o direito de os funcionários inscreverem-se, de boa-fé, em organizações de empregados e participarem de negociações coletivas com os chefes administrativos, sôbre questões de condições de trabalho e politicas pessoais. Estabelece três formass de reconhecimento - informal, formal e exclusivo - cada uma determinada pela percentagem de funcionários públicos pertencentes a uma organização de empregados. Se a percentagem de empregados públicos pertencentes a uma organização é inferior a $10 \%$, a organização recebe reconhecimento informal. Se a percentagem vai de $10 \%$ a $50 \%$, a organização recebe reconhecimento formal. Se vai a mais de $50 \%$, a organização recebe o reconhecimento exclusivo de representante dos empregados.

Quando uma organização de empregados fôr reconhecida informalmente, terá permissão de "apresentar aos funcionários competentes suas opiniões sôbre assuntos do interêsse dos membros. 
A repartição não necessita, contudo, consultar uma organização de empregados dessa categoria para formular a politica de pessoal ou outras que se relacionem com tais assuntos." Se fôr dado reconhecimento formal a uma organização, "a repartição, através dos funcionários adequados, consultará a organização de tempos em tempos para a formulação e implementação de políticas pessoais e práticas, bem como de assuntos que afetem as condições de trabalho do interêsse dos membros." Quando fôr dado reconhecimento exclusivo a uma organização de empregados, "esta terá o direito de agir no sentido da negociação de acôrdos que abranjam todos os empregados da unidade." Será "representada em discussões entre a direção e os empregados... sôbre reclamações, politicas pessoais e práticas, ou outros assuntos que afetem as condições gerais de trabalho dos empregados da unidade." $\left({ }^{32}\right)$

Como os privilégios de representação aumentam com o grau de reconhecimento, os empregados sentem certo estimulo em consolidar -se nos grandes sindicatos. Os privilégios do status de "reconhecimento exclusivo" são tão maiores" que os dos dois outros tipos de reconhecimento, que o decreto parece ter sido feito para incentivar a criação de grandes sindicatos.

Quando os sindicatos de empregados federais aumentam em tamanho, maior número dêles ingressam nos "lobbies" de maior fôrça. As ações "lobbyistas" dos sindicatos postais já foram mencionadas. A Associação Nacional de Portadores de Cartas e a Federação Nacional de Funcionários dos Correios registraram as contas dêsses grupos com despesas de "lobbyismo", num total de mais de 50.000 dólares por ano, durante o qüinquiênio de 19531958. ( ${ }^{33}$ ) Em 1962, sete das trezentas e poucas organizações que declararam despesas de "lobbyismo", assinalaram gastos de mais de 100.000 dólares. Uma delas foi a Federação Unidas dos Funcionários Postais. $\left({ }^{34}\right)$

Embora a história dos sindicatos de empregados federais dê como seu principal interêsse o aumento salarial e a melhoria das políticas pessoais, não é raro unirem-se os empregados e a direção, na busca de objetivos politicos. Sempre que a direção considera uma politica essencial à sua existência ou expansão, ela pode contar com o apoio dos empregados se estiver disposta a incluir nas propostas certas medidas que os empregados considerem benéficas aos seus interêsses.

(32) Decreto Executivo n० 10.988 "Empregados e Chefes no Serviço Federal", Agenda Federal, vol. 27 (19 de janeiro de 1962), págs. 551-556.

(33) Truman, in Junz, op. cit., pág. 129.

(34) Charles L. Clapp, O Congressista: Seu Trabalho como êle o vê (Washington, D.C.: The Brookings Institution, 1963), pág. 163. 
É provável que os sindicatos de empregados venham a absorver gradualmente uma percentagem mais alta de funcionários federais e que venha a haver uma consolidação para obter reconhecimento exclusivo. Nessa eventualidade, a direção estará cada vez mais inclinada a utilizar os meios de mobilização dos empregados em apoio das propostas ao Congresso, sobretudo quando - Congresso se mostrar reticente em favorecer a repartição.

IDEOLOGIA DA BUROCRACIA CIVIL

As relações de poder são inerentes a tôda situação administrativa. $O$ executivo deve estar completamente consciente das implicações inevitáveis dêsse fato e estar preparado para lutar abertamente pelo poder e pela sobrevivência, sob pena de, por falsa modéstia, fraqueza ou ilusão, perder ou restringir sèriamente sua jurisdição e arriscar seus programas. $\left({ }^{(35}\right)$

Os grupos formais de poder que participam na confecção da politica coletiva são constantemente obstados na busca de seus objetivos por outros blocos de pressão - tanto os ramos do govêrno quanto os grupos particulares. Grande parte dessa oposição nasce como resultado do choque de ideologias, baseadas em interêsses distintos. A burocracia civil, contùdo, é tida por neutra e não possuidora de ideologia que se oponha à de outro grupo. O legislador vê a sua relação com a burocracia, principalmente, em têrmos de várias repartições com que êle negocia, por ser designado para comitês ou por causa da área que êle representa. Não se inclina a pensar que essas repartições fazem parte da imensa burocracia federal, mas que são apenas repartições que desempenham, em geral, funções essenciais. É comum êle encarar as repartições em têrmos dos amigos pessoais que tem em Washington, no seu Distrito ou Estado, amigos. dedicados às tarefas
de suas repartições.

O status da burocracia possibilitou o desenvolvimento da sua ideologia ao ponto de se tornar identificável nas operações de tôdas as repartições, mas, devido à sua posição no processo do govêrno, a ideologia escapa à atenção de quase todo mundo, in-
clusive o burocrata.

A ideologia se baseia na maneira pela qual cada repartição encara o seu próprio papel e posição na sociedade. Cada repartição vê a sua existência como resultante da aprovação da sociedade à sua criação, para corresponder a certas necessidades. Na verdade, a repartição foi criada porque certos segmentos do pú(35) Dimock: Jurisdições em Expansão: Estudo de um Caso no Conflito
Butocrático, in Merton et 'al., op. cit., pág. 290 . 
blico mostraram precisar do papel vital que ela desempenharia no fortalecimento e melhoria da vida na América. Para o pessoal da repartição isto significa o direito de satisfazer tantas demandas da sociedade quantas possam ser atendidas dentro da jurisdição da repartição. O escopo da legislação que cria algumas repartições dá grande incentivo à expansão de funções. Se se pode propor novas funções e se pode mostrar à sociedade que o nôvo trabalho da repartição é vital ao melhoramento das condições sociais, a legitimidade da existência da repartição é mais enfatizada e sua permanência se torna mais garantida.

A ideologia pode ser definida nos seguintes têrmos: a existência da repartição é o desejo do público e a evidência do processo democrático na América; a repartição está exercendo serviços que são essenciais ao bem-estar público e seu valor é determinado, em grande escala, pelo modo como usa o conhecimento superior dos seus técnicos, ao considerar os problemas de uma sociedade complexa; a sociedade será aperfeiçoada se a repartição expandir as funções que executa no momento dado, a fim de atender a uma porção maior do público; "há necessidades que, ou não estão sendo atendidas, ou não estão sendo como deveriam e que a repartição será capaz de atender. A repartição procura atingir a maior parcela possivel de eficiência para recompensar a sociedade por confiar-lhe as coisas que deseja sejam feitas pelo govêrno.

As ideologias clássicas negam a justificação do crescimento do govêrno. Estas usariam o argumento da crescente complexidade de nossa sociedade econômica, diriam que êle prova a impossibilidade humana de sucesso pela centralização e defenderiam antes a descentralização, com preferência pelos enérgicos grupos privados .

A ideologia burocrática dá graus de escalonamento de coesão interna a cada repartição e promove seus interêsses com respeito a todos os grupos externos. Justifica o tamanho atual de cada repartição e almeja o crescimento futuro em têrmos das necessidades da sociedade, do serviço e da eficiência. Dirige-se no sentido da segurança e autonomia, que são os interêsses constantes da repartição, e justifica os esforços de expansão - que são feitos para garantir a preservação da repartição. É uma ideologia do progressismo.

Nenhuma fala em nome da burocracia civil inteira. Mas como a burocracia é feita de muitas repartições federais, se a pessoa se afasta da análise de uma ou várias repartiçôes e olha para a burocracia civil como um todo, vê uma burocracia que tem como finalidade básica a preservação e o aumento do papel que representa na sociedade.

Eventualmente, os funcionários públicos podem professar un ponto de vista conservador quanto ao papel adequado do govêrno. 
No entanto, querem ver suas repartições na posição mais forte possivel. Mesmo que a maioria dos burocratas se apegassem a sentimentos conservadores, a defesa que as burocracias fazem da expansão de suas unidades teria como resultado liquido a criação de uma ideologia progressiva. Os empregados de cada repartição querem sempre ver crescerem as funções da mesma, para sentirem maior segurança, prestígio e responsabilidade.

Em 1935, a Administração de Eletrificação Rural foi criada

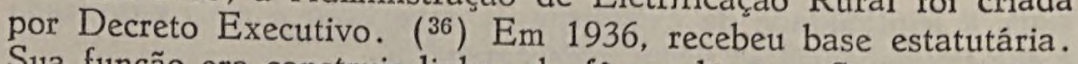
Sua função era construir linhas de fôrça elétrica. Suas operações eram financiadas por arrecadações diretas e por recursos da Corporação Financeira de Reconstrução (CFR). Do ponto de vista dos chefes da repartição, a "operação bem urdida da repartição resultou em presteza de ação e dedicação aos fins públicos." ( $\left.{ }^{37}\right)$

A CFR funcionou como repartição independente até 1 de junho de 1939, quando foi transferida para o Departamento de Agricultura, por lei do Congresso. A consolidação resultou em disputas sôbre organização e politica. O pessoal da CFR opunha-se a ser nivelado com o pessoal do Departamento na politica de salário, nomeações e promoções. "Isto acarretou salários mais baixos para alguns e avanço muito mais lento para todos. Conseqüentemente, a CFR perdeu parte do pessoal que tinha acumulado

A ideologia de cada repartição e, por conseguinte, a burocracia inteira, se dirige no sentido de evilar o que aconteceu à CFR. O temor de diminuição da autonomia está sempre presente nas repartições. Os chefes de repartição vieram a respeitar a politica que administram e a posição que sua repartição mantém. Bernstein disse que "cada carteira ou unidade desenvolveu suas próprias tradições históricas e pontos de vista administrativos costumeiros; e cada unidade desenvolveu, gradualmente, um positivo interêsse pelos seus podêres estatuídos e prestigio politico. Criada em atendimento de uma necessidade particular, cada carteira se agarra firmemente aos seus caminhos separatistas." $\left({ }^{39}\right)$

Algumas repartições se revelaram essenciais à proteção e segurança do público - que são dois fortes símbolos ideológicos. Isto lhes deu maior autonomia e representou uma ajuda significativa na consecução de seus projetos. O Bureau Federal de In-

(36) Vd. Winifred Mc Cullock Relatório sôbre os Funcionários da Administração de Eletrificação Rural, in "Administração Pública e Ação Popás. 621-632.

(37) Ibid., pág. 624

(38) Ibid.

(39) Bernstein, op. cit., pág. 84. 
vestigações (FBI) é um exemplo dêste tipo de repartição. A fôrça que emana de sua posição é visivel no caso da Lei de Aposentadoria do FBI, de 1947. $\left({ }^{40}\right)$

Nesse caso foi esboçada uma lei de privilégios especiais de aposentadoria para os empregados do FBI pelo Departamento de Justiça e levada a ambas as Casas do Congresso. A lei foi rejeitada pela Comissão de Serviço Civil e pelo Departamento do Tesouro. A primeira achava que não deveriam ser concedidos aos funcionários do FBI privilégios especiais e de aposentadoria, superiores aos de todos os outros empregados federais. O último achava que, como dentro do Departamento do Tesouro há repartições de importantes funções investigadoras, tal como o Serviço Secreto, não deveriam ser concedidos beneficios maiores de aposentadoria aos empregados do FBI, do que aos outros empregados federais que exerciam obrigações semelhantes. Apesar da oposição, o projeto passou no Senado "sem debate e sem dissensão." Quase três meses depois, o projeto S. 715 passou na Câmara sem um voto de dissensão. Um curioso expediente foi utilizado para obter tal aprovação. Conseguiram que os agentes aposentados do FBI, muitos dêles cidadãos ilustres, escrevessem aos legisladores regionais, expondo razões para a aprovação da lei.

Ao considerar a solução dada no caso dessa lei, o leitor deverse lembrar de que "a profunda e vasta preocupação com a segurança dos Estados Unidos e a preocupação correlata com o bem-estar do FBI, como agência dedicada à proteção de nossa segurança", muito influenciou a aprovação da lei. ( $\left.{ }^{41}\right)$

Pode-se obter uma melhor compreensão da ideologia da burocracia civil ao se examinar alguns dos elementos que são inerentes à forma organizacional da burocracia. Como a ideologia de qualquer grupo é muitas vêzes o resultado de acontecimentos históricos e tendências sociais, êsses fatôres podem lançar alguma luz na presente ideologia.

\section{Caracteristicas inerentes à Burocracia e as Demandas de Eficiência da Sociedade}

Peter Blau afirmou que as características básicas da organizacão burocrática são "a especialização, a hierarquia de autoridade, o sistema de normas e a impersonalidade." ( ${ }^{42}$ ) Segundo

(40) Joseph F. Marsh JR., A Lei de Aposentadoria do FBI, in Stein, op. cit., pág. 649-660.

(41) Ibid., pág. 652 .

(42) BLAu. Burocracia na Sociedade Moderna (New York: Randon House, Inc., 1956), pág. 19. 
Max Weber "é um dado da experiência universal que o tipo de organização administrativa puramente burocrática... é, do ponto de vista exclusivamente técnico, capaz de atingir o mais alto grau de eficiência." ( ${ }^{43}$ ) Declarou também que "a precisão, a rapidez, a clareza, o conhecimento dos arquivos, a subordinação estrita, a redução de atritos e de gastos com material e pessoal - são condições elevadas ao grau ótimo na administração puramentte birocrática." ( $\left.{ }^{44}\right)$

Estas declarações indicam que a ênfase da burocracia é sôbre a forma, a ordem e a rotinização, para obter o grau máximo de eficiência. De fato, as burocracias aparecem quando uma sociedade complexa busca os meios de execução sistemática de suas funções. As repartições atuais do govêrno estão aptas a induzir o público e os legisladores ao reconhecimento de certos problemas e à necessidade de resolvê-los. Ao mesmo tempo, mostram que são capazes de enfrentar determinado problema com maior eficiência do que qualquer outro grupo. Dêsse modo, a característica inerente da burocracia da repartição, combinada com a sua posição estratégica, dá-lhe maior vantagem para ser investida na autoridade de que necessita para expandir suas funções. A cada aumento de tamanho e funções ela se torna mais segura, pelo fato de que a sociedade dela depende cada vez mais. A demanda de eficiência pelo público é a preocupação constante dos membros da repartição: "Basta dizer que a ordem: 'Seja eficiente! é um fator fundamental da organização sôbre as decisões dos membros de qualquer repartição administrativa; e que a verificação da observância dêsse mandamento é função básica do processo de inspeção." ( $\left.{ }^{45}\right)$

Por haver hoje em dia milhares de normas de certo modo protetoras das partes da estrutura burocrática que põem em risco a eficiência da repartição, há uma forte tendência para superar tais fraquezas pela expansão de tamanho da maquinaria burocrática, até atingir o ponto desejado de eficiência.

$U_{m}$ estudioso olhou por interessante ponto de vista o assunto das reclamações de ineficiência da burocracia. Êle acha que os individuos, que estão em contato com os grupos burocráticos, podem sentir $\sim$ se desamparados diante da poderosa burocracia, especialmente se a esta escapam as circunstâncias excepcionais do seu caso e ela o coloca dentro de uma categoria geral. O reque-
rente frustrado pode tentar aliviar seus sentimentos chamando a

(43) Weber, A Teoria da Organização Social e Econômica, traduzido por A. M. Henderson e Talcott Parsons (Glencoe, Illinois: The Free Press,
1947 ), pág. 337 .

(44) Gerth e Mills, op. cit., pág. 214.

(45) Herbert, A. Simon, Criação de Decisões e Organização Administra-

tiva, in Merton et. al., op. cit., pág. 129. 
atenção para a ineficiência burocrática. $\left.{ }^{46}\right) \mathrm{O}$ mesmo autor declara que, "coloquialmente, o têrmo "burocracia" se tornou um epiteto que significa ineficiência e fita vermelha no govêrno." $\left.{ }^{47}\right)$

Os ideólogos clássicos, particularmente, äfirmam que as burocracias do govêrno são ineficientes porque não sofrem o pêso da competição, como as firmas privadas. Na luta pelo mercado, as companhias eficientes vencem $e$ as ineficientes morrem. Dêsse modo, o lucro torna-se a perfeita medida realista de eficiência, para a qual não há sucedâneo no govêrno.

$\mathrm{O}$ apêgo geral à imagem de ineficiência da burocracia, pela mesma sociedade que demanda eficiência, estimula cada repartição a melhorar os seus programas e métodos e a demonstrar eficiência em têrmos quantitativos, ao público e aos inquéritos do Congresso. Ilustra bem o ponto a concessão de prêmios aos servidores civis que dão sugestões para a melhoria da eficiência. $\mathrm{O}$ Diretor da Comissão de Serviço Civil, JoHn MAcY, fazendo conferência em clubes civis e profissionais, deu seguidos exemplos dessas recompensas e dos dólares hipotèticamente economizados através das sugestões.

\section{Mudança de Opinião quanto ao Papel do Govêrno}

Como se mostrou na introdução dêste artigo, no comêço do século $\mathrm{XX}$, as funções da burocracia civil eram limitadas em comparação com a situação atual. Esta condição resultou, em grande parte, da concepção geral do papel do govêrno. A doutrina dominante até então tinha sido a do laissez faire, doutrina de não interferência do govêrno. A crise do século $\mathrm{XX}$ trouxe um desafio a essa doutrina, do que emergiu a criação de muitas novas repartições do govêrno federal. Estas foram criadas para executar funçôes e exercer sôbre a vida e os negócios do povo americano um contrôle que, até então, não havia interessado ao Govêrno Federal." ( ${ }^{48}$ )

Tais modificaçōes no aspecto geral do papel do govêrno colocaram o rótulo de "estado administrativo" nos Estados Unidos.

A característica mais notória do estado administrativo é a proeminência da administração pública. Quando o govêrno passa de um papel relativamente passivo para outro crescentemente ativo seu mecanismo de ação inevitàvelmente se expande. Esse mecanismo assume o ca-

(46) Blau, Burocracia na Sociedade Moderna, pág. 102-103.

(47) Ibid., pág. 13.

(48) John J. Corson, Chefes Executivos para o Serviço Federal (New York: Columbia University Press, 1952), pág. 16. 
ráter de estabelecimento permanente porque o govêrno é levado a assumir responsabilidades ininterruptas que só podem ser preenchidas pela continuidade de operações. (49)

$\AA$ parte as guerras modernas com suas economias dirigidas pelo govêrno, a maior influência sôbre a modificação dos conceitos tradicionais quanto ao papel do govêrno foi a Grande Depressão e o "New Deal." Até o comêço do "New Deal", o papel do govêrno, com raras exceções, era de não-intervenção. Com a introdução do "New Deal" surgiram muitas repartições administrativas. Dentre os novos organismos governamentais, componentes do moderno estado administrativo, estavam a Tennessee Valley Authority, o Departamento de Habitação e Financiamento, a Carteira de Aeronáutica Civil, a Comissão de Garantias e Valôres, - Departamento Nacional de Relações de Trabalho, a Corporação Federal de Depósitos de Seguros, a Comissão de Energia Atômica, a Administração de Crédito Agrícola, o Banco de Exportação e Importação, a Administração de Operações Exteriores e a Agência Federal de Segurança.

MÁrio EINAudi fêz esta interessante observação sôbre as novas repartições:

Muitas ganharam poder de ação discricionária pois não era possivel, sem elas, a intrepretação nem a execução eficiente de algumas intrincadas leis. As novas repartições adquiriram fortes podêres semilegislativos. Em si mesmo, foi um estágio, não um acontecimento nôvo, mas seu impacto foi sentido com mais fôrça nos anos seguintes a 1933 , pois os novos podêres exerciam-se sôbre áreas muito mais importantes e sensiveis de problemas humanos. As novas repartições adquiriram podêres de investigação e de execução também. $\left({ }^{50}\right)$

Tais modificações tiveram sôbre o público americano um impacto difícil de calcular em suas dimensões. A burocracia tornou -se essencial à preservação da fôrça e segurança da América. Até a imagem do burocrata mudou. Foi reconhecido como executor de papel essencial no crescimento e desenvolvimento da América. O homem de negócios não tinha resposta para tôdas as' doenças da América. De fato, "houve marcante melhoria geral da atitude do público para com o servidor civil a partir de

(49) Fritz Morstein MARX, A Função Social da Administração Pública,
in Marx, op. cit., pág. 97 .

(50) Einaudi, op. cit., pág. 137.

(51) Janowrrz et al., op. cit., pág. 281. 
Além de modificar o papel da burocracia civil, o "New Deal" também criou uma burocracia imensa, enchendo-a de gente que tomava as repartições do govêrno como pontos de referência para realizarem seus objetivos de participação nos problemas existentes. Muitos dos intelectuais, juristas e estudantes da nação, encararam o "New Deal" como a oportunidade de participação na "experiência democrática radicada no solo americano e condicionada pelas realidades americanas contemporâneas. O serviço público tornou-se a alternativa para as frustrações e o pessimismo que dominavam as atividades dos homens sensiveis de grandes capacidades." ( $\left.{ }^{52}\right)$ A afluência dessas pessoas para as novas repartições deu a cada uma delas uma visão progressiva de seu nôvo papel, o que constitui um dos fatôres mais significativos no desenvolvimento da presente ideologia.

Sôbre as características dêstes servidores do "New Deal" e de sua atitude geral para com o seu trabalho, Herman Miles Somers escreveu: "Vem dêles a tradição de propor e iniciar idéias, programas e reformas. Foi dêles a taref̧a de "educar" o Congresso e, até, de lutar por avanços politicos." ( ${ }^{53}$ ) A alteração de atitudes se tornou explicita quando os burocratas começaram a aparecer em comitês do Congresso em proporções nunca antes verificadas, para apoiar os programas das suas repartiçóes.

Sôbre a burocracia, durante as administrações de Roosevelt e Truman, Woll declarou:

... a burocracia estava imbuída, de maneira geral, da idéia de que deveria ter um papel na regulamentação da vida econômica do pais e poder fazer recomendações legislativas ao Congresso $e$ ao Presidente. Tanto Roosevelt quanto Truman preferiram uma burocracia dotada de iniciativa, em vez de uma burocracia indiferente e passiva, mesmo que aquilo significasse, de tempos em tempos, certa oposição aos desejos do Presidente. ( $\left.{ }^{54}\right)$

A ênfase dada à burocracia progressiva durante as duas décadas de 1933 a 1953 ficou um pouco em conflito com a politica da Administração de Eisenhower que demandava o afastamento do Govêrno Federal de muitas áreas em que vinha participando desde 1933. Ao tempo em que Eisenhower ingressou na Casa Branca e esperavam se grandes mudanças na máquina administrativa, a revista Fortune fêz o seguinte comentário:

Quando os bons homens de negócios, convidados pelo Sr. Eisenhower, ingressarem nos gabinetes de Was-

(52) EINAUdi, op. cit., pág. 135.

(53) Somers, A Burocracia Federal e a Mudanşa na Administração, Revista de Ciência Politica Americarta, vol. 48, $\mathrm{n}^{\circ} 1$ (março, 1954), pág. 137. (54) Op. cit., pág. 152. 
hington não hão de se ver completamente cercados de amigos, nem verão todos os corredores tinindo de camaradagem. Haverá muita gente que os olhará com desconfiança. Os homens de alto nivel do Fair Deal como Oscar Chapman e Oscar Ewing terão saido, é claro, mas uma legião de pequenos "Oscares" permanecerá, ou estará nos formigueiros burocráticos, gozando nomeações a longo prazo, ou colocados fora de mira, no serviço público. O problema não é de competência. Muitos são bastante competentes. O problema é de ideologia. Encontram-se em posições-chave. Pois, digarse o que se disser da natureza não politica das nomeações civis federais, foram os agentes dedicados do New Deal e do Fair Deal que estiveram por cima, durante os vinte anos de Roosevelt e Truman. (55)

Os oito anos de Eisenhower na Casa Branca não parecem ter afetado consideràvelmente a ideologia da burocracia. Os Republicamos verificaram que é muito difícil reduzir as funções ou o tamanho de uma repartição, depois de se ter mobilizado uma clientela que depende da repartição e tem contato com o Congresso.

\section{O Serviço Civil -}

O serviço civil de carreira para o Govêrno Federal fundou-se com a aprovação da Lei Pendleton, em 1883. A lei formalizou a crença de que, até certo ponto, as posições do govêrno devem depender da aptidão e adequação, em vez da filiação a um partido. Desde a aprovação da lei, o sistema patronal, ou de benefícios partidários, cedeu cada vez mais lugar ao sistema do mérito, de modo que, hoje, $91 \%$ dos empregados federais são fruto do sistema do mérito. $\left({ }^{56}\right)$ Com o crescimento numérico dos empregados públicos providos pelo sistema do mérito, desenvolveu-se um sentimento crescente de coesão e continuidade. Sem mêdo de serem substituidos na mera base de fatôres politicos, muitos empregados federais podem fazer carreira dentro de suas repartições. Dêsse modo, desenvolveu-se o esprit de corps dentro da repartição e seus membros o observam com senso de honra e orgulho; e cultivam a oportunidade de mostrar a seus associados o progresso da repartição, em têrmos de métodos de execução do trabalho,
funções exercidas, número de empregados e dinheiro gasto.

(55) Os Pequenos Oscares e o Serviço Civil, Fortune, vol. 47 (janeiro,
pág. 77 .

(56) Associação de Servidores Públicos do Estado de Utah, "Porque o Sistema do Mérito para os Servidores do Estada." (Salt Lake City, Utáh),
pág. 3 . 
A Comissão de Serviço Civil muito contribui para imbuir os empregados de carreira com o esprit de corps. É o que se viu em 1961 quando o Presidente da Comissão disse que os objetivos primordiais do serviço civil federal incluiam a atração dos maiores talentos da nação para o serviço federal, o desenvolvimento do talento no pessoal de carreira, a obtenção do sistema de remuneração adequado e imparcial e a elevação do prestígio do serviço federal. ( ${ }^{57}$ ) A Comissão também traz maior coesão para as repartições ao informar os empregados federais sôbre a legislação que, de um modo ou de outro, afeta o serviço civil. Faz isso na página intitulada "Observando a Legislação" do Jornal do Serviço Civil.

O sistema do mérito foi usado com muita eficiência por Roosevelt e Truman para estabelecer uma burocracia dedicada aos programas progressistas. "Ao colocar êstes novos servidores civis no sistema do mérito, Roosevelt estava tomando a iniciativa mais necessária à proteção do "New Deal"... O Presidente Truman colocou grande parte da burocracia sob a proteção do sistema do mérito, antes de enfrentar as incertezas da eleição de 1948." ( $\left.{ }^{58}\right)$

O sistema do mérito facultou a existência do senso de coesão e continuidade na burocracia civil, e seu uso foi fator de importância na criação da presente ideologia. O sucesso do sistema do mérito foi demonstrado quando o Presidente Eisenhower tentou reduzir o número dos servidores civis. Levantou-se contra êle um sentimento de desconfiança dentro da burocracia e o resultado foi que poucas alterações foram feitas.

\section{Novas Repartições}

Com a mudança do papel do govêrno, o Govêrno Federal assumiu mais e mais programas novos. Wallace S. Sayre salientou o fato de que "os novos programas governamentais que requerem inovações têm freqüentemente sido confiados às repartições recém-criadas, servidas por pessoal recém-recrutado." ( $\left.{ }^{59}\right)$ A repartição recém-formada preocupa-se imediatamente em estabelecer a própria legitimidade e em adquirir a maior autonomia possivel. Precisa provar que é essencial ao bem-estar da sociedade. Precisa mostrar que presta serviço importante e o faz com marcante eficiência. Para isso se esforça por aumentar e ativar a clientela, o que em geral significa desenvolvimento de funções

(57) Seis Objetivos Primordiais do Serviço Civil Federal, "Bom Govêrno", vol. $78, \mathrm{n}^{\circ} 10$ (outubro, 1961), pág. 3 .

(58) Woll, op. cit., pág. 151.

(59) SAYRe in Objetivos para os Americanos, pág. 291. 
e tamanho. Esforça-se por obter as relações mais próximas com os blocos de poder do processo de criação politica, o qual, atingido, torna mais fácil o crescimento.

Como a maioria dos empregados, incluindo os chefles executivos da nova repartição, são, também, novos no serviço público, têm êles uma viva preocupação com a segurança e o prestigio de suas próprias posições.

É importante notar que, na criação de novas repartições, bem como nos niveis máximos das já estabelecidas, os chefes executivos são amplamente convocados de fora do govêrno. Muitos são chefes de emprêsas, lideres acadêmicos e profissionais. ( $\left.{ }^{60}\right)$ Deixam suas posições para ingressar no serviço do govêrno, na maior parte pela "oportunidade do serviço público; oportunidade de atingir objetivos politicos; oportunidade de trabalho mais interessante e estimulante; oportunidade de melhorar as perspectivas da carreira fora da experiência do govêrno; desejo de prestígio, estima ou deferência; desejo de influir nos assuntos públicos e de exercer posição de poder." ${ }^{61}$ ) Cada um dêsses pontos mostra porque o chefe executivo estará ansioso por ver a repartição aumentar em tamanho e funções. Mostram-se geralmente pressurosos por usar sua posição no govêrno na criação de novos programas e por tomar decisões importantes sôbre assuntos dificeis, de natureza social e econômica.

Esses novos lideres muito contribuem para estabelecer e perpetuar a ideologia básica de suas respectivas repartições, o que, por sua vez, expande a ideologia da burocracia em geral.

\section{O Executivo no Plano Federal}

Visto qưe a repartição do govêrno age sob a direção de seu porta-voz, os chefes executivos federais devem ser discutidos, pelo menos ligeiramente, para determinar em que sentido êstes, enquanto individuos, influenciam a ideologia da burocracia.

Origem, do Executivo - Dois estudos recentes mostram que os chefes executivos federais procedem, com predominância, de áreas urbanas. O estudo de W. LLOYD WARNER e outros mostrou que "as grandes cidades representam-se na proporção de 182 para cada grupo de 100 , sugeridos ao acaso." ( $\left.{ }^{62}\right)$ A apuração de WARNER incluiu 10.851 funcionários executivos civis federais, desde o nivel de gabinete até o grau 14 do Quadro Geral, ou

(60) Corson, op. cit., págs. $16,17,21$.

(61) BERnSteIn, op. cit., pág. 139.

(62) Nossos Servidores Públicos, Corporação Carnegie de New York, Trimestral, vol. 11, n 3 (julho, 1963), pág. 2. 
seu equivalente. $\left({ }^{63}\right) \mathrm{O}$ estudo de Dean E. Mann indicou que, dentre os chefes executivos politicos, $90 \%$ viviam em áreas metropolitanas quando designados para o serviço do govêrno, embora apenas $59 \%$ da população total vivesse nessas áreas em 1950. Mann sugere que pode ser esta uma razão dos conflitos entre os pontos de vista executivo e legislativo, dado que a maioria dos senadores nasceu nas áreas rurais, conforme apurou em trabalho recente. $\left({ }^{64}\right)$

Os resultados dêsses estudos também sugerem que a origem dos funcionários executivos federais pode ser importante para a compreensão da ideologia progressiva da burocracia. As áreas metropolitanas são predominantemente liberais na sua visão do papel do govêrno. Uma esmagadora maioria de altos funcionários executivos, provenientes de áreas urbanas, afeta, sem dúvida, a ideologia da burocracia no sentido de posições mais elaboradas e mais progressivas.

O Nivel de Instrução - O nivel de instrução dos funcionários executivos federais também deve ser "levado em consideração. A pesquisa de Warner demonstrou que $9 \mathrm{em} 10$ têm treino universitário, 8 em 10 são diplomados, $25 \%$ têm o grau de licenciados, $10 \%$ têm o grau de Doutorado, e 10\% têm o grau de Bacharéis em Direito. ( ${ }^{65}$ ) No grupo de funcionários do Serviço Exterior, o nivel de instrução é ainda maior: $88 \%$ têm grau universitário $33 \%$ são licenciados, $13 \%$ têm o grau de Doutorado, e $8 \%$ são bacharéis ou doutôres em Direito. Estes algarismos superam longe os números totais de instrução de adultos do sexo masculino nos Estados Unidos, dos quais apenas $13 \%$ freqüentaram universidade. Dentre os executivos de emprêsas privadas, verificou-se que $57 \%$ têm grau universitário. ( $\left.{ }^{66}\right)$

$\mathrm{O}$ alto nivel de instrução dos funcionários executivos federais indica que muitos intelectuais dos Estados Unnidos ocupam, ou ajudam a educar os que ocupam altas posições no govêrno. Não há razão para presumir que êles sejam menos liberais na sua visão do papel do govêrno do que os intelectuais de fora do govêrno. $\mathrm{Na}$ verdade, é evidente que a razão pela qual muitos estão servindo em posições do govêrno é sentirem que estão capacitados a usar o seu conhecimento para tomar decisóes práticas de considerável importância. As categorias intelectuais tornam-se fonte

(63) W. Lloyd Warner, Paul P. Van Riper, Normal H. Martin, e ORvis F. Coluins, Uma Nova Interpretação do Chefe Executivo de Carreira no Serviço Público, Revista de Administração Pública, vol. 22. $n^{0} 4$ (dezembro, 1962), pág. 188.

(64) Trimestral Carnegie, pág. 2.

(65) Warner, et al., O Funcionário Executivo Federal Americano (New Haven, Connecticut: Yale University Press, 1963), pág. 11.

(66) Ibid., págs. 15, 19. 
importante de funcionários executivos das novas repartições. Os programas laterais de entrada no serviço do govêrno foram criados, sobretudo, para atrair os indivíduos bem educados para o govêrno, sem ter de começar por baixo.

O Reitor da Escola Superior de Cidadania e Assuntos Públicos, de Maxwell, relatou recentemente que, em 1962, enviou cartas a 800 ex-alunos da Escola Superior de Maxwell que estavam trabalhando para o govêrno e pediu a cada um que lhe mandasse uma nota sôbre sua carreira. $\left({ }^{67}\right)$ O relatório está cheio de declarações indicando que o serviço público oferece oportunidades incomparáveis para os que desejam ter uma carreira exaltada, criadora e operosa - fatôres êstes que mais parecem atrair a "intelligentsia."

O Estudo assinala porque entram no serviço público êsses homens instruidos que poderiam ganhar maiores salários em outras fontes. Para a pessoa de alto nivel de instrução que aceita menor recompensa financeira pelo seu esfôrço, há grandes oportunidades em adquirir, no govêrno, uma posição que lhe permita participar em alguns dos programas mais revolucionários e provocadores da história da América. Disse um funcionário executivo federal que deixou seu emprêgo bem remunerado na indústria porque "tomo decisões mais importantes em Washington em um dia do que tomava em um ano na indústria." ( $\left.{ }^{68}\right)$

\section{SUMÁRIO CONCLUSIVO}

O desenvolvimento da população americana, seu crescimento urbano e sua posição de liderança mundial coloca a burocracia civil em posição muito favorável com respeito à sua ideologia e ao seu papel como grupo de poder. O atual sistema de poder internacional bipolarizado coloca muitas pressões, antes desconhecidas, sôbre os Estados Unidos, sendo uma delas a de apresentar : $:$ m sistema de govêrno capaz de enfrentar problemas econômicos c sociais, de maneira superior aos sistemas comunistas. Êsses fatôres estimulam um govêrno mais progressivo, o que por sua yez acarreta a expansão da burocracia.

A mudança de atitude em relação à função do govêrno trouxe uma mudança significativa na atitude em relação ao servidor público. Dá-se-lhe um papel mais e mais vital na América. Uma pesquisa da revista Fortune em 1940, para determinar o prestígio dos empregados do govêrno em comparação com os empregados na emprêsa privada, em condições de igualdade de salários e de

(67) Stephen K. Bailey, O Estimulo do Serviço Público, Jornal do Serviço Público Civil, vol. $4, \mathrm{n}^{\circ} 1$ (julho-setembro, 1963), págs. 5-9.

(68) Ibid., pág. 652 . 
trabalho, demonstrou que $50 \%$ dos entrevistados preferiam trabalhar na emprêsa privada, $40 \%$ no govêrno dos Estados Unidos, e $10 \%$ não manifestaram preferência. ${ }^{69}$ Esste inquérito foi feito após o New Deal, que foi um periodo de considerável melhoria para o prestígio do emprêgo público.

Em 1954, Morris Janowitz e Deil Wright fizeram um estudo sôbre o prestigio do servidor público, do qual concluiram que "o prestígio do emprêgo público passou a uma nova fase e perdeu muito do seu status de cidadão de segunda classe." Descobriram que dos 764 membros da população adulta das íreas metropolitanas de Detroit que pesquisaram, $56 \%$ prefeririam trabalhar para o govêrno dos Estados Unidos do que para uma firma particular se os salários fôssem idênticos. Trinta por cento declararam que preferiam trabalhar para firma particular, e $14 \%$ mostraram-se indiferentes ou não deram opinião. $\left({ }^{70}\right)$

O prestígio do serviço público cresce e provàvelmente continuará a crescer, enquanto o povo sentir necessidade de pedir ao govêrno respostas para os problemas. Quanto maior o prestígio do burocrata, maior a inclinação da sociedade para confiar à burocracia novas tarefas. Tal sentimento coloca a ideologia da burocracia civil em posição muito saudável.

Cada vez mais se reconhece a burocracia como representativa do povo. Com o crescimento das repartições em número e em funções, mais gente se associa a êsses grupos do govêrno, de uma maneira ou de outro. Woll observou que "a burocracia é um setor altamente representativo do nosso govêrno, em muitos respeitos mais representativo do que o Congresso; deve-se acrescentár que há casos em que a burocracia pode ser mais representativa do que o Presidente." ("71) Isto se nota mais claramente quando se observa que os grupos privados procuram representação nas repartições do govêrno e são poucos os americanos que deixam de associar-se, de uma maneira ou de outra, com um ou mais dêsses grupos privados.

O papel e a ideologia da burocracia também gozam do apoio de opiniốes acadêmicas como a de Seymour Martin Lipset:

$\mathrm{E}$ inerente às estruturas burocráticas a tendência para transferir conflitos da arena política para a administrativa. A ênfase constante na necessidade de critérios objetivos, como base de ajustamento de conflitos, permite às instituições burocráticas desempenhar impor-

(69) Morris Janowitz e Deil. Wright, O Prestigio do Emprêgo Público, 1929 e 1954, Revista de Administração Pública, vol. 16, $\mathrm{n}^{\circ} 1$ (Inverno, 1956), pág. 17 .

(70) Ibid., págs. 16-17.

(71) Wol., op. cit., pág. 172. 
tantes papéis de conciliação. Dêsse modo, as várias pressões para ampliar as normas e práticas burocráticas fortalecem o consenso democrático. $\left({ }^{72}\right)$

Êste é um exemplo marcante do modo pelo qual a burocracia se apresenta como bastião da democracia, o que é, como vimus, parte da ideologia da burocracia civil.

Tais observações não pretendem sugerir que a burocracia civil funcione sem contrôle. De fato, qualquer repartição precisa estar preparada para fazer acôrdos e até ceder em alguns de seus propósitos, quando entra na arena política. Como foi visto no caso da Lei do Serviço Diplomático, há grupos de poder no processo de criação de política que oferecem oposição ios programas da repartição. A repartição precisa também considerar a possibilidade de oposição às suas atividades, partindo das investigações do Congresso, das inspeções do judiciário e, por vêzes, da observação direta do Presidente ou de comissão por êle designada.

A história da burocracia civil durante as três últimas décadas indica, todavia, que sua posição lhe permite pedir apoio aos blocos de poder, sempre que se encontra em posição arriscada, ou que as condições se tornam difíceis. Tanto o Presidente quanto os grupos de poder podem dar apoio a uma repartição quando o Congresso relutar em agir a seu favor. Se o Presidente deixar de dar o apoio, a repartição tem outras fontes de poder a que se dirigir imediatamente, a menos que seus objetivos estejam totalmente discrepantes das tendências esposadas pelo govêrno.

A competição entre as repartições foi freqüentemente apresentada como um empecilho à facilidade com que o poder burocrático se manifesta. Apesar de esta competição cercear a liberdade do uso do poder, tudo indica que ela conduz mais vêzes à justa posição de funções do que à vitória de uma repartição sôbre outra. Bernstein fêz esta observação esclarecedora: "Ulma repartição sòzinha pouco pode fazer sem se meter nos assuntos das outras. Um funcionário executivo federal dificilmente pode tratar dos seus próprios assuntos sem mexer com os dos outros." $\left({ }^{73}\right)$

Considerando-se todos os fatôres, parece válido afirmar $\approx$ se que a atitude pública tende a justificar, cada vez mais, as características marcantes da burocracia civil como grupo de pocer, e que a tempo está do lado da burocracia. Os impedimentos sôbre as repartições federais raramente deixam-nas sem grupos de poder para assisti-las no exercicio do seu próprio poder. Elas estão colocadas entre os participantes mais significativos da criação da
politica coletiva americana.

(72) Seymor Martin Lipset, O Homem Politico: As Bases Sociais da Politica (Garden City, N.Y.: Doubleday \& Company, Inc., 1960), pág. 37.

(73) Bernstein, op. cit., pág. 78. 